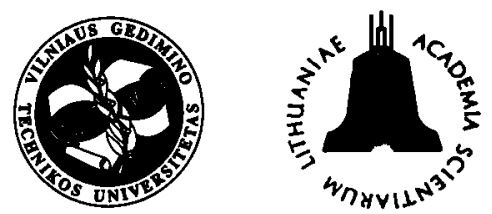

JOURNAL OF CIVIL ENGINEERING AND MANA

http:/www.vtu.lt/english/editions

2003, Vol $I X$, No 2, 146-152

\title{
THE INFLUENCE OF POLYMER LATEX AND SILICA FUME ADDITIVES ON THE PROPERTIES OF CEMENT MORTAR AND CONCRETE
}

\author{
Bronius Vektaris, Edita Smetonaité, Vytis Vilkas \\ Laboratory of Modification Building Materials of Institute of Architecture and Construction, \\ Tunelio g.60,LT-3035 Kaunas, Lithuania.E-mail: asi@asi.lt
}

Received 08 Jan 2003; accepted 13 May 2003

\begin{abstract}
The article maintains that while mixing acryliated latex, cement, fillings, and relaxing additives, flexible, resilient and well sticking to concrete mortars are obtained. Their properties - the lenghtening of a mortar layer, tensile strength and strength of adhesion to concrete - may be regulated while changing the quantities of cement and plasticisers. 10-30\% silica fume and Stoniškiai carbonate opoca additives grant to usual Portland cement mortar or concrete the resistance to sulfate corrosion. When the quantity of cement in concrete exceeds $400 \mathrm{~kg} / \mathrm{m}^{3}$, an increased quantity of hydraulic additive is necessary 20-30\%. Opoca additive ensures a better Portland cement resistance to sulfate action than the same quantity of $\mathrm{CaCO}_{3}$ and Norwegian silica fume mixture. This fact is explained by a larger activity of opoca. However silica fume activity may be increased by reducing silica fume to smaller units, for example by mixing it with coarse aggregate. In hardening, concrete silica fume and other hydraulic additives react with $\mathrm{Ca}(\mathrm{OH})_{2}$ deriving from cement, that's why in hardened concrete free lime diminishes and less secondary expansion units are created. There are vivid peaks of $\mathrm{CaSO}_{4} \cdot 2 \mathrm{H}_{2} \mathrm{O}$ and $\mathrm{Ca}(\mathrm{OH})_{2}$ in XRD patterns of decayed samples. This research shows that gypsum formation is the main reason of concrete decay in $\mathrm{Na}_{2} \mathrm{SO}_{4}$ solution.
\end{abstract}

Keywords: repair mortar, tensile strength, protection, plasticity, concrete, hydraulic additives, sulfate resistant.

\section{Intoduction}

Traditional cement mortars and concretes are brittle; they demonstrate poor adhesion to the foundation and poor resistance to sulfate corrosion. The above-mentioned properties are eliminated or improved with the use of polymeric and very small mineral concrete additives [1-6].

Cement mortars and concretes with polymeric additives are used for protecting of concrete and reinforced concrete constructions, as well as for repairing works and other purposes. Several series of European standards have been prepared that are also adopted in Lithuania [7, 8]. Research work with polymercement materials carried out at the Institute of Architecture and Construction during which local raw materials, polymeric dispersions, and other additives are used [9]. Some materials have already been produced and utilised in Lithuania.

A number of authors determined that polymeric additives influence hydration and hardening of Portland cement, since the interaction with their component is fluctuating, especially with $\mathrm{Ca}(\mathrm{OH})_{2}$. During water elimination from the hardening product they either form or do not form films; the additives may stick separate concrete components and additionally strengthen the concrete [ 10 , 11]. The mechanism of the interaction of Portland ce- ment and the polymere has not been yet fully discovered, especially in the case of silica fume that also reacts with $\mathrm{Ca}(\mathrm{OH})_{2}$.

Silica fume is a highly active hydraulic additive [12]. The activity of the hydraulic additives, ie their ability to tie free lime $\left(\mathrm{Ca}(\mathrm{OH})_{2}\right)$ deriving from the solution, is an essential factor in the increase of the traditional cement resistance to sulfate waters. When the reinforced concrete equipment in water - purification and in ports includes Portland cement of an ordinary composition with a great amount of $\mathrm{C}_{3} \mathrm{~S}$ and $\mathrm{C}_{3} \mathrm{~A}$, the sulfate ions of the environmental water in the concrete pores react with free lime thus forming the gypsum less soluble than $\mathrm{Na}_{2} \mathrm{SO}_{4}$. During its crystallisation in the concrete pores the volume of the hard phase increases 2,3 times. If $\mathrm{Na}_{2} \mathrm{SO}_{4}$ reacts with tricalcium aluminium hydrate $\left(\mathrm{C}_{3} \mathrm{AH}_{6}\right)$ and as a result ettringite $\left(\mathrm{C}_{3} \mathrm{~A} \cdot 3 \mathrm{CaSO}_{4} \cdot 32 \mathrm{H}_{2} \mathrm{O}\right)$ is formed, the volume of the hard phase increases 4,8 times [13]. Interior tensions occure in the concrete as well as microgaps, which may result in the concrete decay. However the secondary ettringite is also formed in the free lime presence. Therefore the additives that tie $\mathrm{Ca}(\mathrm{OH})_{2}$ may be useful for the increase of cement sulfate resistance.

The work aims at the analysis of the mortar deformative properties its tensile strength, the degree of ad- 
hesion to concrete, the concrete sulfate resistance, the influence of the improving additives on the properties of the cement mortar and concrete, when the ordinary Portland cement is used.

\section{Materials and methods}

Portland cements produced by the joint-stock company "Akmenès Cementas" CEM I 42.5 R and CEM II $A-M / 42.5$, sand from the Rizgoniai sand-pit, $4 / 10 \mathrm{~mm}$ broken stone, polymeric dispersions, silica fume of two varieties - Norwegian granulated "Holla Metal" microsilica, further marked as NMS and the Ukrainian untreated silica fume further marked as UMS were used in the research work. For comparison the local hydraulic additive - the Stoniškiai carbonate opoca powder - was used. Taking into consideration that there are about $50 \%$ $\mathrm{CaCO}_{3}$ in carbonate opoca, another Karpenai limestone powder additive was used to determine its effect. Organic polymeric plasticisers and additives (methylcellulose, etc) were introduced, too.

Portland cement CEM II A-M/42.5 included 9-10\% $\mathrm{CaCO}_{3}$ and $4 \%$ gypsum. The clinker of this cement contained $55,8 \% \mathrm{C}_{3} \mathrm{~S}$ and $9,7 \% \mathrm{C}_{3} \mathrm{~A}$, while the CEM I $42.5 \mathrm{R}-50,7 \% \mathrm{C}_{3} \mathrm{~S}$ and $9 \% \mathrm{C}_{3} \mathrm{~A}$.

The activity of various kinds of silica fume and opoca depends on their fineness. However, there is a difficulty in determining the quality of fineness, since when fined the light powder aggregates and forms small clods and lumps. Therefore an attempt was made at pulverizing silica fume together with the filling to determine its activity according to the special fastened method invented by the authors of the article. It is founded in the following procedure: $1 \mathrm{~g}$ of the examined material is poured into 11 plastic large-necked cylindric bottle together with some amount of the filling and $500 \mathrm{ml}$ of substantial $\mathrm{Ca}(\mathrm{OH})_{2}$ solution. The mixture is warmed up to $45 \pm 5^{\circ} \mathrm{C}$ temperature, and after some time it is possible to determine how many milligramms of $\mathrm{CaO}$ were joined to $\mathrm{lg}$ of the investigated material [14].

The extension and tensile strength of the mortar were determined during the production and testing of $2 \mathrm{~mm}$ thick plates of which, after hardening, the samples of the necessary shape and size were cut. Adhesion to concrete was analysed by tearing the stuck concrete plates off.

The bending and compressive strength as well as resistance to sulfate corrosion was determined by testing $4 \times 4 \times 16 \mathrm{~cm}$ size prisms produced according LST 1413.8 and LST 1356 (in some cases $2 \times 2 \times 2 \mathrm{~cm}$ cubes). The fastened method of determining the resistance to aggressive solutions [15], was employed when the samples $(4 \times 4 \times 16)$ were immersed in $\mathrm{Na}_{2} \mathrm{SO}_{4}+3 \mathrm{M} \mathrm{NaOH}$ solution. The samples were parallelly analysed regarding their frost resistance according to the LST 1428.17 fastened method.

\section{Results and discussion}

Differently prepared and modified latexes that included different additives did not show positive results. The mortar layers with these latexes were hard and unelastic. The acrylated vinyl acetate based on copolymeric latex (abridge - acrylated latex) may also serve the purpose. Acrylated latex of various lots acrylic latex with amount of total solids 48-51\% was employed. When mixed with cement and fillings, this latex acquired different properties. If various amounts of latex are added to the cement and sand mixture (1:1 according to mass), the hardening of cement slows down, but the compressive strength increases (Fig 1).

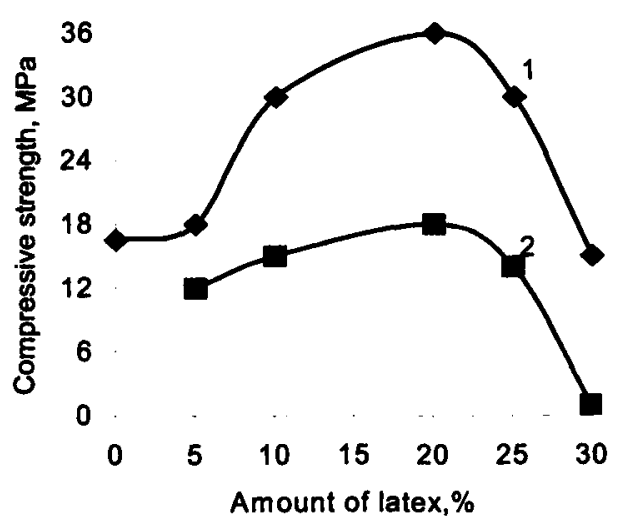

Fig 1. The effect of the amount of added acrylated latex on the compressive strength. 1 - plain latex; 2 - plasticised latex. $\mathrm{W} / \mathrm{C}=(\mathrm{L}+\mathrm{W}) / \mathrm{C}=0,4$

When $15 \%$ of latex from the mass of cement is added, the compressive strength increases nearly twice. The plasticised latex ( $15 \%$ plasticiser from the latex mass) additives considerably decrease the compressive strength (Fig 1). When in the mixture the amount of latex (especially plasticised) is increased up to $25-30 \%$, the elastic and flexible mortars (0,5-2 mm thick) were investigated when regarded as the protective cover of the cracking concrete.

These mortars well adhere to the concrete surface and thus cover the microcracks. When such a cover is flexible and elastic, new cracked constructions do not form in the concrete.

The properties of the mortar elasticity and flexibility depend on numerous factors. Fig 2 demonstrates how the tensile strength as well as adhesion to the concrete of the mortar layer varies with the change of the amount of the cement in the mixture.

The mortar including $25 \%$ cement demonstrates the greatest tensile strength and adhesion to concrete. Although when stretched such a mortar shows the smallest extension, yet the extension is too big, resulting in $180 \%$ and more [16].

During stretching, the extension of the layer samples when depends on the amount of cement, the alteration have been observed within the range of $20 \%$. However, 


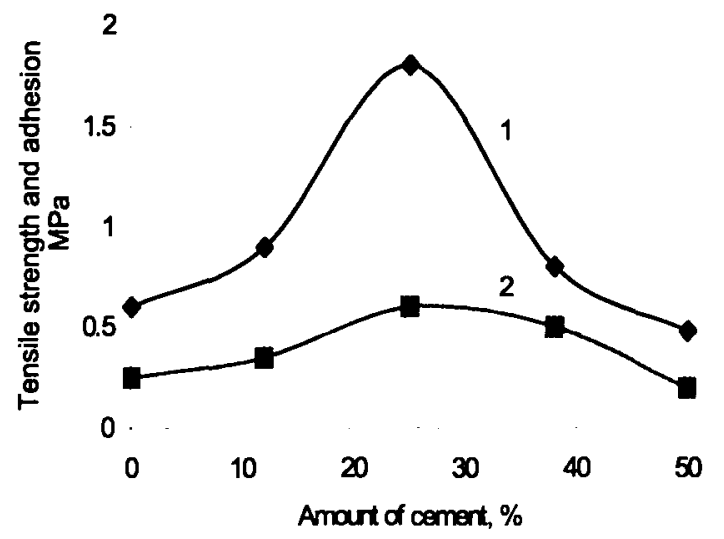

Fig 2. The effect of the amount of CEM II A-M/42.5 on the tensile strength (1) and adhesion to concrete (2) of latex mortar

the extension mostly depends on the amount of plastciser in the latex (Fig 3).

The samples of the mortar layer without a plasticiser extend about $50 \%$. With the increase of the amount of the plasticiser (up to $25 \%$ ) the extension increases about four times. Moreover, the value of the extension depends on the period of the sample hardening (Fig 3).

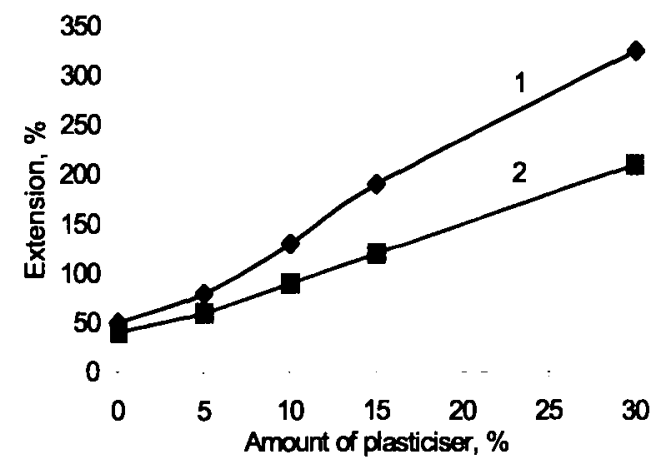

Fig 3. The effect of the amount of plasticiser on the extension of mortar layer: 1 - after 7 days, 2 - after 28 days

However, with the increase of the amount of the plasticiser in mortar, the mortar tensile strength and the adhesion to concrete decrease (Fig 4). When the latex without a plasticiser is used, the tensile strength is 2,4 $\mathrm{MPa}$. When the amount of plasticiser reaches $25 \%$, the tensile strength decreases up to $0,2 \mathrm{MPa}$ (twelve times). The strength of adhesion, in its turn, changes from $1 \mathrm{MPa}$ to $0,18 \mathrm{MPa}$ (about 5,5 times). Therefore, with the alteration of the plasticizer amount in the mixture, the change of the properties of the hardened product is possible in a rather wide range.

Acrylic latex contains about $50 \%$ of water. In fact, when a greater amount of water is added, the properties of the mortar improve [16].

It is obvious that in some components the mortar composition has a different effect on the properties of the product. The pouring of $15 \%$ from the latex mass of both water and plastciser is welcome, since it increases

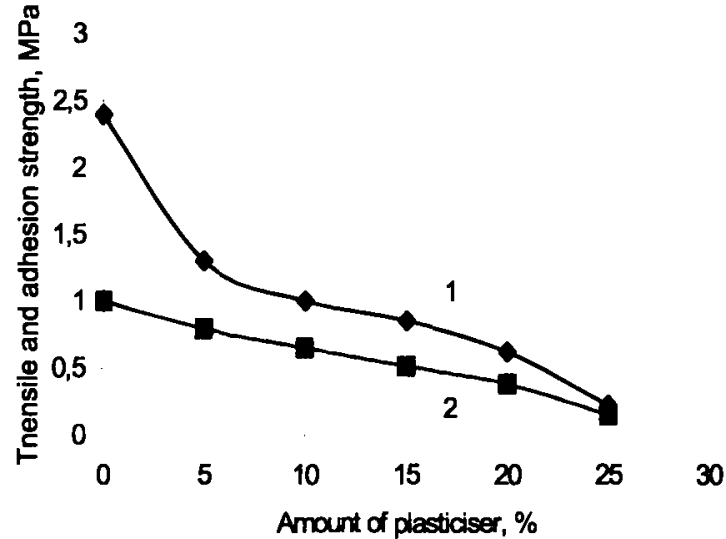

Fig 4. The effect of the plasticiser amount on the tensile strength (1) and adhesion (2)

the tensile strength. The adhesion strength also increases when up to $0,4 \%$ methylcelluloze is added to mortar. The silica fume additive does not have a considerable effect on this type of mortar.

The role of silica fume as well as its efect on the properties of the mortar and concrete were also analysed, first of all, the ability of different varieties of this material to react with $\mathrm{Ca}(\mathrm{OH})_{2}$.

Fig 5 shows the ability of the NMS, the UMS, and the opoca powder to join $\mathrm{CaO}$ from the solution after their keeping at $45 \pm 5{ }^{\circ} \mathrm{C}$ temperature for 3 days.

Silica fume mixed with sand joins the double amount of $\mathrm{CaO}$ when prepared to a fined silica fume. The activity of UMS even without additional fining is high enough.

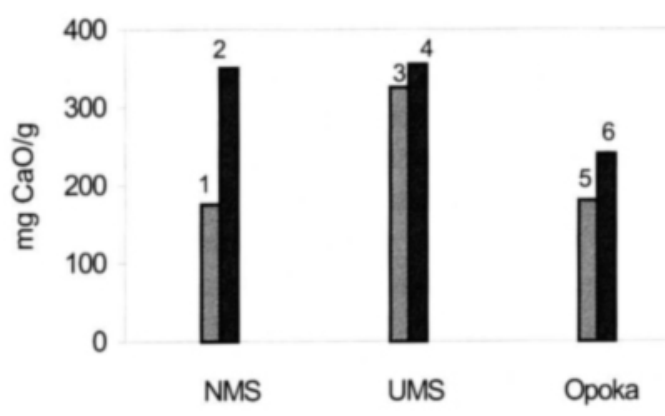

Fig 5. The effect of the fining of the NMS, the UMS and the opoca powder mixtures with sand (1:4) on their activity after 3 days of testing: 1, 3 and 5 - unfined material mixed with sand (1:4);2, 4 and 6 - pulverized 3 min with sand $(1: 4)$

The activity of opoca is smaller than that of silica fume. However taking into consideration the fact that the amount of opalic $\mathrm{SiO}_{2}$ in opoca is only about $50 \%$, it is important to recognise that carbonate opoca is an active hydraulic additive of cement and concrete.

It has been determined that when $1 \mathrm{~g}$ of the NMS is poured into a plastic bottle together with $40 \mathrm{~g}$ granite broken stone, and, by producing both rotatory and shaking movements during 4-5 minutes the NMS fractions get fined, and thus their additional fining is avoided. 
Table 1. The effect of the NMS, limestone powder $\left(\mathrm{CaCO}_{3}\right)$ and opoca powder additives on the resistance of concrete samples $(4 \times 4 \times 16 \mathrm{~cm})$ to $5 \% \mathrm{Na}_{2} \mathrm{SO}_{4}$ solution. CEM I $42.5 \mathrm{R}$ and lignosulphonate plasticiser SBS were used. W/C $=0,5$

\begin{tabular}{|c|c|c|c|c|c|c|}
\hline \multirow{2}{*}{$\begin{array}{l}\text { Amount } \\
\text { of } \\
\text { cement } \\
\mathrm{kg} / \mathrm{m}^{3}\end{array}$} & \multirow{2}{*}{$\begin{array}{l}\text { Amount of } \\
\text { additives, } \% \text {, } \\
\text { of cement } \\
\text { masss }\end{array}$} & \multirow{2}{*}{$\begin{array}{c}\text { Samples } \\
\text { density } \\
\mathrm{kg} / \mathrm{m}^{3}\end{array}$} & \multirow{2}{*}{$\begin{array}{c}\text { Tensile/ } \\
\text { compressive } \\
\text { strength after } 28 \\
\text { days } \\
\text { of hardening, MPa }\end{array}$} & \multicolumn{3}{|c|}{ Properties after 375 days immersion } \\
\hline & & & & $\begin{array}{l}\text { deformation, } \\
\mathrm{mm} / \mathrm{m}\end{array}$ & $\begin{array}{c}\text { changes of } \\
\text { mass, } \\
\%\end{array}$ & $\begin{array}{l}\text { condition } \\
\text { of samples }\end{array}$ \\
\hline 440 & - & 2390 & $7,6 / 61,4$ & $+1,43$ & $+0,42$ & broken \\
\hline 440 & 0,7 SBS & 2250 & $6,8 / 48,4$ & $+6,17$ & $+3,51$ & broken \\
\hline 440 & $15 \mathrm{CaCO}_{3}$ & 2330 & $7,1 / 59,3$ & $+1,67$ & $+2,00$ & broken \\
\hline 440 & 15 NMS & 2310 & $7,6 / 71,0$ & $+4,85$ & $+2,15$ & broken \\
\hline 440 & $\begin{array}{c}10 \mathrm{CaCO}_{3} \\
15 \mathrm{NMS} \\
0,7 \mathrm{SBS}\end{array}$ & 2380 & $8,7 / 57,6$ & $-0,09$ & $+0,79$ & good \\
\hline 350 & $\begin{array}{c}12,5 \mathrm{CaCO}_{3} \\
12,5 \mathrm{NMS}\end{array}$ & 2380 & $8,3 / 62,8$ & $+0,76$ & $+2,19$ & good \\
\hline 440 & $\begin{array}{l}20 \text { opoca } \\
0,7 \text { SBS }\end{array}$ & 2390 & $7,3 / 76,4$ & $-0,91$ & $+0, \overline{73}$ & good \\
\hline 440 & $\begin{array}{l}30 \text { opoca } \\
0,7 \text { SBS }\end{array}$ & 2480 & $8,1 / 79,2$ & $+0,33$ & $+0,39$ & good \\
\hline 395 & $\begin{array}{l}11 \text { opoca } \\
0,7 \text { SBS }\end{array}$ & 2410 & $7,3 / 58,0$ & $+0,3$ & 0,92 & good \\
\hline 350 & $\begin{array}{l}25 \text { opoca } \\
0,7 \text { SBS }\end{array}$ & 2330 & $6,8 / 58,8$ & $-0,20$ & $+0,35$ & good \\
\hline
\end{tabular}

Table 2. Resistance of fine concrete (cement:sand $=1: 3)$ samples $(4 \times 4 \times 16 \mathrm{~cm})$ with additives of the NMS and the UMS to $5 \%$ $\mathrm{Na}_{2} \mathrm{SO}_{4}$ solution. CEM I 42,5R was used

\begin{tabular}{|c|c|c|c|c|c|c|}
\hline $\begin{array}{c}\text { Amount } \\
\text { of addi- } \\
\text { tives, \% }\end{array}$ & \multicolumn{3}{|c|}{ Tensile/compressive strength, $\mathrm{MPa}$, after } & \multicolumn{3}{c|}{$\begin{array}{c}\text { Properties of samples after immersion them in } 5 \% \\
\mathrm{Na}_{2} \mathrm{SO}_{4} \text { solution for } 24 \text { days }\end{array}$} \\
\cline { 2 - 6 } & $\begin{array}{c}28 \text { days } \\
\text { of } \\
\text { hardening }\end{array}$ & $\begin{array}{c}18 \text { months of } \\
\text { immersion in } \\
\text { water }\end{array}$ & $\begin{array}{c}18 \text { months of } \\
\text { immersion in } 5 \% \\
\mathrm{Na}_{2} \mathrm{SO}_{4} \text { solution }\end{array}$ & $\begin{array}{c}\text { deformation, } \\
\mathrm{mm} / \mathrm{m}\end{array}$ & $\begin{array}{c}\text { change of } \\
\text { mass, \% }\end{array}$ & $\begin{array}{c}\text { condition of } \\
\text { samples }\end{array}$ \\
\hline- & $8,1 / 66,5$ & $10,5 / 87,5$ & $8,2 / 58,0$ & $+1,59$ & $+1,98$ & broken \\
\hline 5 NMS & $8,1 / 58,5$ & $10,4 / 74,0$ & $10,0 / 68,0$ & $+1,38$ & $+1,89$ & broken \\
\hline $10^{*}$ & $8,7 / 66,0$ & $10,4 / 74,0$ & $11,5 / 77,0$ & $+0,44$ & $+1,49$ & small changes \\
\hline $30 *$ & $7,4 / 52,0$ & $7,4 / 63,0$ & $11,4 / 57,0$ & $+0,18$ & $+1,65$ & good \\
\hline 5 UMS & $8,9 / 66,0$ & $9,6 / 72,0$ & $9,6 / 72,0$ & $-0,78$ & $+0,85$ & small changes \\
\hline $10^{*}$ & $9,0 / 60,8$ & $10,4 / 67,0$ & $10,0 / 70,0$ & $-1,2$ & $+0,75$ & good \\
\hline $20 *$ & $8,0 / 5,6$ & $10,4 / 6,0$ & $8,7 / 60,0$ & $+0,18$ & $+1,01$ & good \\
\hline $30 *$ & $7,4 / 43,2$ & $8,1 / 55,0$ & $7,9 / 60,0$ & 0,00 & $+0,73$ & good \\
\hline
\end{tabular}

The data data presented in Table 1 shows what effect the NMS, the opoca and limestone additives have on concrete when the samples $(4 \times 4 \times 16 \mathrm{~cm})$ are kept in $5 \% \mathrm{Na}_{2} \mathrm{SO}_{4}$ solution.

The Portland cement CEM I $42.5 \mathrm{R}$ was used during the experiments. In fact it is not sulfate-resisting cement. Therefore the samples without other additives than lignosulphonate plasticiser SBS and $15 \%$ limestone in 375 days got decayed in the mentioned solution. When hardening they have extended and their mass has insreased. The same happened with samples including $15 \%$ NMS additive because this additive was not fined and therefore demonstrated inconsiderable activity.

When the NMS were used together with $10 \%$ limstone, the samples did not decay. When the amount of cement in the concrete decreased up to $350 \mathrm{~kg} / \mathrm{m}^{3}$, the concrete is resistant with $12,5 \% \mathrm{NMS}+12,5 \%$ $\mathrm{CaCO}_{3}$. It proves the positive effect of $\mathrm{CaCO}_{3}$, which has already been mentioned in scientific literature [17-
19]. The opoca additive also increases the concrete resistance to sulfate corrosion (Table 1). When the amount of cement does not exeed $400 \mathrm{~kg} / \mathrm{m}^{3}, 11 \%$ of opoca is sufficient. When it is $440 \mathrm{~kg} / \mathrm{m}^{3}$, the amount of opoca should make $20-30 \%$ of the cement mass. Similar results of sulfate resistance were achieved with the samples $(4 \times 4 \times 16 \mathrm{~cm})$ produced of the fine concrete $(1: 3)$ with the use of the CEM II A-M/42.5 cement which included $9 \% \mathrm{CaCO}_{3}$ (Table 2).

Strength of the samples either without additives or with UMS additive after having been kept in $\mathrm{Na}_{2} \mathrm{SO}_{4}$ solution for a year started decreasing, but with the 20-30\% NMS it has no changed (it is not demonstrated in Table 2). After a year and a half of beeing kept in an aggressive environment the strength of the samples without additives decreased by $12,8 \%$. In two years there appeared cracks on the edges of the samples, however, the strength of the samples with additives increased. It is important to mention that the mass of all the samples 
kept in $5 \% \mathrm{Na}_{2} \mathrm{SO}_{4}$ solution increased, especially during the first twelve months - up to $0,73-1,65 \%$. Later it altered less, and reached $0,75-1,99 \%$. The greatest mass alteration was noticed in the samples either without additives or with $5 \%$ NMS additive. The smallest changes up to $0,73-1,01 \%$ observed when the UMS additive was used. The greatest and smallest deformations of samples correspond to the mass alterations. The greatest deformations up to $1,59 \mathrm{~mm} / \mathrm{m}$ take place either in the samples without additives or with $5 \%$ NMS. The sample deformations in the case of the UMS additive are the smallest. It has also been determined that these samples were not deformed by corrosion (Table 2 ).

The dilution of Portland cement with $\mathrm{CaCO}_{3}$ as well as the mechanical decrease of the amounts of $\mathrm{C}_{3} \mathrm{~S}$ and $\mathrm{C}_{3} \mathrm{~A}$ in a certain percentage do not protect agains longterm aggressive impact of $\mathrm{Na}_{2} \mathrm{SO}_{4}$ solution. However, at the beginning of the hardening process $\mathrm{CaCO}_{3}$ additive stimulates $\mathrm{C}_{4} \mathrm{AH}_{\mathrm{x}}$ and $\mathrm{C}_{3} \mathrm{~A} \cdot \mathrm{CaCO}_{3} \cdot \mathrm{H}_{11}$ formation and suppresses the formation of $\mathrm{C}_{3} \mathrm{AH}_{6}$ [13], that is why this additive is harmless and welcome. Its action is complemented by the active $\mathrm{SiO}_{2}$. The increase of sample mass in $\mathrm{Na}_{2} \mathrm{SO}_{4}$ solution (Tables 1,2 ) occurred because of the formation the reaction products of low solubility when $\mathrm{Na}_{2} \mathrm{SO}_{4}$ reacted with $\mathrm{Ca}(\mathrm{OH})_{2}$ and other cement minerals. With the increase of the samples mass and the volume of some components, the samples extended. The mass of the samples with the UMS increased considerably less $(2-2,3$ times $)$ than the mass of the samples without additives. The samples extended significantly, or, in other cases, they contracted and showed no signs of decay. The suitable amount of silica fume in the concrete makes 10 to $20 \%$ of the cement mass and this corresponds to the ratio 2 to 1 of free lime derived from cement and the added active $\mathrm{SiO}_{2}$.

The influence of the additionally pulverised NMS additives on the concrete resistance to the aggressive solutions and frost has also been investigated throughout the research. Granulated silica fume was fined while_intensively mixing it in tum with the broken stone, sand, cement, and the humid concrete mixture of whitch $4 \times 4 \times 16$ $\mathrm{cm}$ samples were formed. After 28 days they were immersed into $8 \% \mathrm{Na}_{2} \mathrm{SO}_{4}+3 \mathrm{M} \mathrm{NaOH}$ solution, as it is presented in [15], and the deformations were measured. Analogical actions were carried with the concrete without additives and the concrete with an opoca additive. Another series of hardened samples was cooled up to $\geq-16^{\circ} \mathrm{C}$ and warmed up to $18 \pm 2{ }^{\circ} \mathrm{C}$ in $5 \% \mathrm{NaCl}$ solution. The samples without additives extended intensively for about 60 days (Fig 6), but in 10-20 days the positive effect of the NMS and opoca was discovered.

The samples without additives extended about 3,5 $\mathrm{mm} / \mathrm{m}$. The higher extension of the samples [14] may be explained by the secondary extension or by formation of the $4 \mathrm{CaO} \cdot 0,9 \mathrm{Al}_{2} \mathrm{O}_{3} \cdot 1,1 \mathrm{SO}_{3} \cdot 0,5 \mathrm{Na}_{2} \mathrm{O} \cdot 16 \mathrm{H}_{2} \mathrm{O}$ (the so-called the fourth phase).

However, during the samples cooling the negative effect of NMS was discovered. After 40 fastened cool-

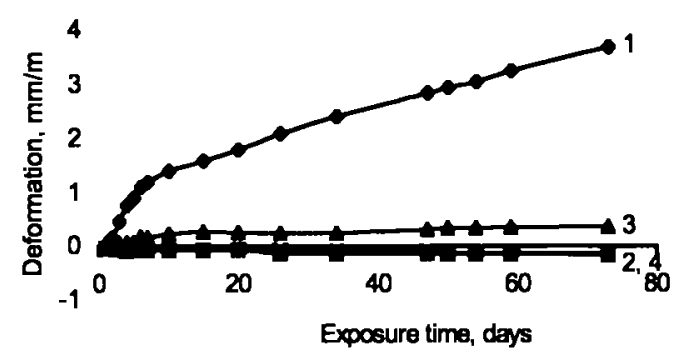

Fig 6. The effect of additionally pulverised NMS additive on deformation of samples, when their have been treating accordingly [14]. 1 - without additive, 2 - with 12,5 NMS, 3 - with $25 \%$ NMS, 4 - with $25 \%$ opoca additive (CEM II A-M/42.5)

ing cycles (about 120 ordinary freeze-thaw cycles) the samples with NMS additive started cracking (Fig 7). The samples without NMS and the ones with the opoca additive did not crack. The samples immersed in an aggressive solution after keeping them for about 360 days did not crack either. Therefore it is important to improve the frost resistance of the concrete, which included silica fume.

The decreased concrete resistance to frost, when the silica fume additives are employed, is most probably depends on "fresh pucolanisation" phenomenon that requires additional investigation.

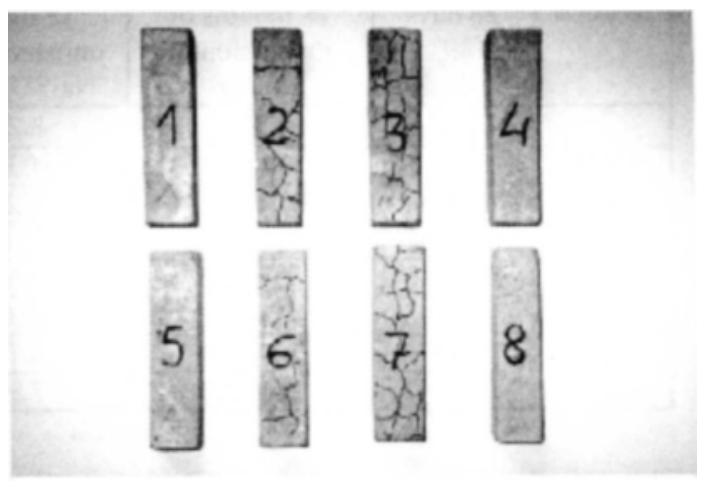

Fig 7. The frost resistance of concrete samples after 40 freeze-thaw cycles (sample 2, 3,6,7) and after 145 cycles freeze-thaw (sample 1, 4, 5, 8). 1 - 4 samples with CEM I $42.5 \mathrm{R} ; 1,5$ - 8 with CEM II A-M/42.5. 1, 5 - without additives; 2, 6 - with $12,5 \%, 3,7$ - with $25 \%$ NMS additive, 4,8 - with $25 \%$ opoca

The investigation of the cement stone resistance to sulfates was carried out too. For this purpose $2 \times 2 \times 2 \mathrm{~cm}$ cubes were formed from the CEM I 42.5R cement paste with certain additives or without them and were immersed in $18 \pm 2{ }^{\circ} \mathrm{C}$ temperature water and in $5 \% \mathrm{Na}_{2} \mathrm{SO}_{4}$ solution. During 1,5 year the samples of Portland cement stone immersed in $5 \% \mathrm{Na}_{2} \mathrm{SO}_{4}$ solution decayed.

The XRD investigation of the samples showed that essential difference between the patterns was the appearance of gypsum $\mathrm{CaSO}_{4} \cdot 2 \mathrm{H}_{2} \mathrm{O}(0,76,0,306 \mathrm{~nm}$ peaks) or bassanite $\mathrm{CaSO}_{4} \cdot 0,67 \mathrm{H}_{2} \mathrm{O}(0,602 ; 0,374 \mathrm{~nm})$ peaks in the decayed samples (because the prepared samples were 
dried in $110^{\circ} \mathrm{C}$ temperature). Other $\mathrm{X}$-ray diffraction patterns did not show it (Fig 8).

The Portland cement samples with $30-50 \%$ opoca additives remained in the best state. In their X-ray diffraction patterns the gypsum peaks has not been discovered. However, the samples with $10 \% \mathrm{CaCO}_{3}$ and $5 \%$ NMS got dacayed. The same happened with the samples having no $\mathrm{CaCO}_{3}$, but including $15 \% \mathrm{NMS}$. Their XRD patterns showed the peaks of both $\mathrm{Ca}(\mathrm{OH})_{2}$ and $\mathrm{CaSO}_{4} \cdot 2 \mathrm{H}_{2} \mathrm{O}$ (Fig 8).
The samples with $10 \% \mathrm{CaCO}_{3}$ and $15 \% \mathrm{NMS}$ did not decay. Thus the results of the XRD research allow the conclusion that the main destructive factor of the concrete in $\mathrm{Na}_{2} \mathrm{SO}_{4}$ solution is the formation of the secondary gypsum:

$\mathrm{Ca}(\mathrm{OH})_{2}+\mathrm{Na}_{2} \mathrm{SO}_{4}+2 \mathrm{H}_{2} \mathrm{O} \rightarrow \mathrm{CaSO}_{4} \cdot 2 \mathrm{H}_{2} \mathrm{O}+2 \mathrm{NaOH}$.

Gypsum may form when the solution includes free $\mathrm{CA}(\mathrm{OH})_{2}$, because $\mathrm{Ca}(\mathrm{OH})_{2}$ in solution $\mathrm{Na}_{2} \mathrm{SO}_{4}$ increase and soluble gypsum decrease. Obviously, free $\mathrm{Ca}(\mathrm{OH})_{2}$
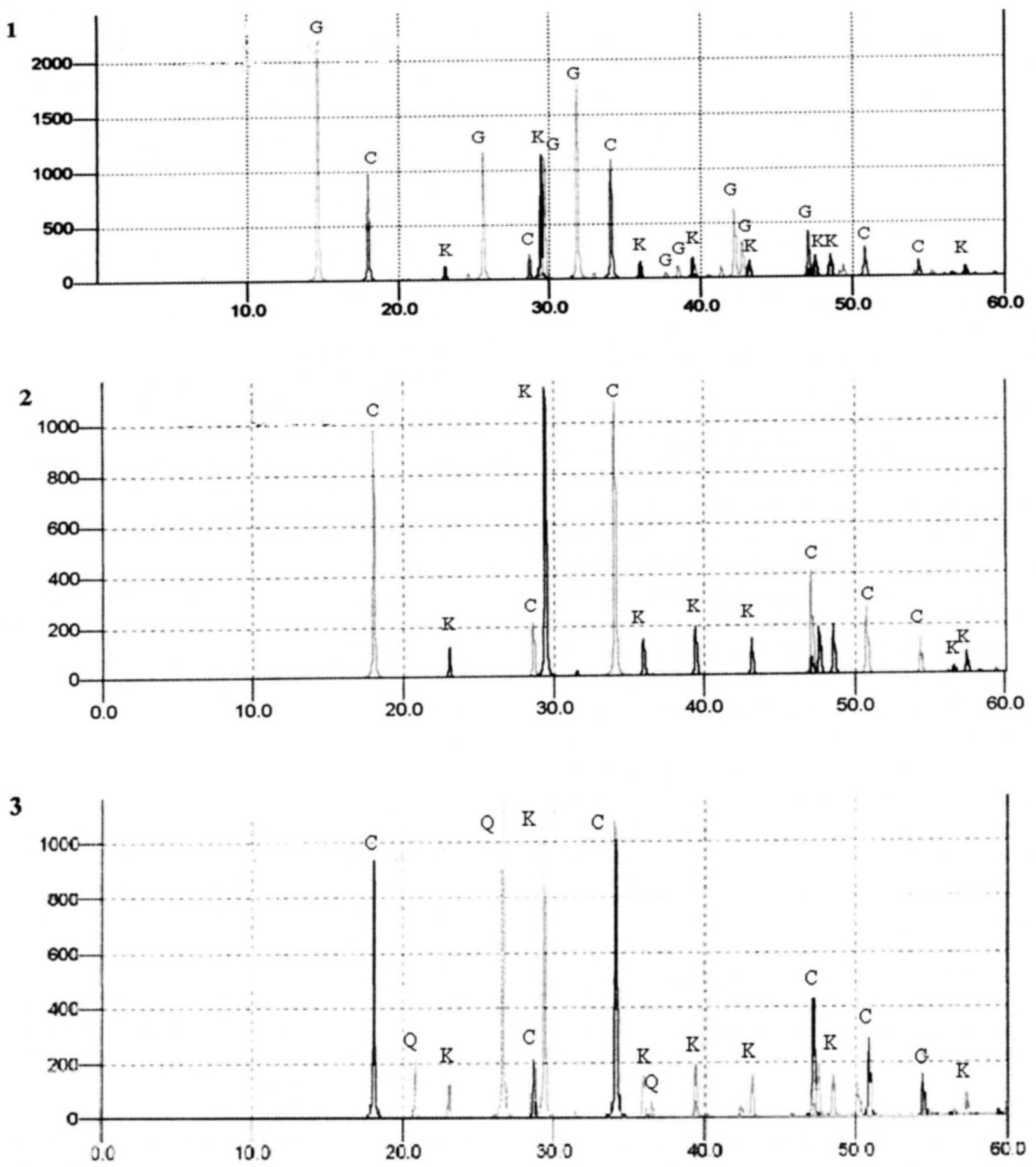

Fig 8. XRD patterns of cement stone samples exposed for 3 years in $5 \% \mathrm{Na}_{2} \mathrm{SO}_{4}$ solution. I - $85 \% \mathrm{CEM}$ I $42.5+10 \%$ $\mathrm{CaCO}_{3}+5 \%$ NMS; $2-75 \%$ CEM I $42.5+10 \% \mathrm{CaCO}_{3}+15 \% \mathrm{NMS} ; 3-70 \%$ CEMI $42.5+25 \%$ NMS. G - bassanite, $\mathrm{C}-\mathrm{Ca}(\mathrm{OH})_{2}, \mathrm{~K}$ - calcite, $\mathrm{Q}-$ quartz 
is tied by active amorphic $\mathrm{SiO}_{2}$ that is found both in opoca and silica fume.

\section{Conclusions}

1. When mixing acrylic latex, cement, fillings, and the relaxing additives in respective ratious, elastic, flexibile, and well adhering to the concrete mortars are produced. They may be used for the repairing and protection of the conrete and reinforced concrete constructions. The extension of the mortar layers as well as their tensile strength and the strength of adhesion to the concrete can be controlled with the change of the amounts cement and plasticiser.

2. Silica fume and the Stoniškiai carbonate opoca additives increase the resistance of ordinary Portland cement concrete to sulfate corrosion. The effectivness of anti-corrosive additives depends on their origin, activity, and amount of the additives. When the amount of cement exceeds $400 \mathrm{~kg} / \mathrm{m}^{3}$, greater amount of hydraulic additive $(20-30 \%)$ is required.

3. The opoca additive guarantees a stronger sulfate- resistance of Portland cement than a certain amount of the $\mathrm{CaCO}_{3}$ and silica fume mixture. This fact could be explained by the greater activity of opoca. The activity of silica fume may be increased by fining, ie mixing it with a coarse filling.

4. The fastening method of determining the potential activity of silica fume and other hydraulic additives has been prepared.

5. On the basis of experiments, the conclusion can be made that in the hardening concrete silica fume and the other hydraulic additives react with $\mathrm{Ca}(\mathrm{OH})_{2}$ derived from the cement. As a result, in the hardening concrete the amount of free lime decreases and less secondary extending compaunds are formed. The XRD patterns of the decayed samples demonstrate the peaks of gypsum, and $\mathrm{Ca}(\mathrm{OH})_{2}$. The formation of gypsum makes the chief reason of the concrete decay.

6. The NMS additive may become the reason of the decrease of the concrete resistance to frost. The frost resistance of the concrete that hardens for a longer time period (the testing encompossed a full year) increases.

\section{References}

1. The possibility of polymer resins for concrete and reinforced concrete structures (Применение полимерных смол в бетонных и железобетонных конструкциях). Contribution to the USSR conference. Vilnius, 1971. $168 \mathrm{p}$. (in Russian).

2. Chandra, S.; Fladin, P. Interaction of polymers and organic admixtures on Portland cement hydration. Cement and Concrete Research, 1987, Vol 17, p. 875-890.

3. Curbugzen, R.; Dilgres, P. Dispersion polymeric powder peculiarity of behaviour in dry constructional mixture.
Building Materials (Строительные материалы), 1999, No 3, p. 10-12 (in Russian).

4. Evdokimov, A. Dry water diluting latexes for constructional materials and paints. Building Materials (Строительные материалы), 1999, № 11, p. 20-21 (in Russian).

5. Ganesh Babu, E.; Surya Prakash, P. V. Efficiency of silica fume in concrete. Cement and Concrete Research, 1995, Vol 25, No 6, p. 1273-1283.

6. Durekovic, A. Cement pastes of low water to solid ratio: an investigation of the porosity characteristic under the influence of a superplasticiser and silica fume. Cement and Concrete Research, 1995, Vol 25, No 2, p. 365-375.

7. EN 1504 Parts 1-10. Products and systems for the protection and repair concrete structures.

8. EN 1542, 1543, 1766, 1767, 1770, 17799, 12188, 12189, 12190. Products and systems for the protection and repair concrete structures - Test methods.

9. Smetonaité, E. Investigation of repair of mortar concrete constructions. Materials Science (Medžiagotyra), 2000, Vol 6, No 6, p. 72-75.

10. Cherkinsky, X. Polymer-cement concrete (Полимерцементный бетон). Moscow, 1984. 213 p. (in Russian).

11. Ramachandran, V. S. Concrete admixtures (Добавки в бетон). Moscow: Strojizdat, 1988, p. 298-381.

12. Vektaris, B.; Vilkas, V. The influence of silica fume on Portland cement hardening and concrete properties. Chemical Technology (Cheminè technologija), 1999, No 2 (11), p. 60-64 (in Lithuanian).

13. Alekseev, S.; Ivanov, F.; Modry, S.; Shissl, P. Durability of reinforced concrete in aggressive media (Долговечность железобетона в агрессивных средах). Moscow, 1990. 93 p. (in Russian).

14. Vektaris, B.; Vilkas, V. Investigation of silica fume activity. Materials Science (Medžiagotyra), 2001, Vol 7, No 2, p. 123-126.

15. Li, G.; Le Bescop, P.; Morranvile, M. Expansion mechanism associated with the secondary formation of the $U$ phase in cement-based systems containing high amount of $\mathrm{Na}_{2} \mathrm{SO}_{4}$. Cement and Concrete Research, 1996, Vol 25, No 2, p. 195-201.

16. Smetonaité, E. The influence of modified coatings for repair constructions. Materials Science (Medžiagotyra), 2002, Vol 8, No 1, p. 109-111.

17. Zelic, J.; Krstulovic, R.; Tkalčec, E.; Krolo, P. The properties of Portland cement - limestone-silica fume mortars. Cement and Concrete Research, 2000, Vol 30, p. 145152.

18. Kaminskas, R.; Vektaris, B. The influence of carbonate opoca on Portland cement hardening and properties. Chemical Technology (Cheminè technologija), 1999, No 2 (11), p. 65-74 (in Lithuanian).

19. Kakali, S.; Tsivilis, E.; Aggeli M. Bati. Hydration Products of $\mathrm{C}_{3} \mathrm{~A}, \mathrm{C}_{3} \mathrm{~S}$ and Portland Cement in the Presence of $\mathrm{CaCO}_{3}$. Cement and Concrete Research, 2000, Vol 30, No 7, p. 1073-1077. 